Elsevier

JRI 00307

\title{
Genetic effects on quantitative variation in serologically detected H-Y antigen
}

\author{
Mark Shapiro and Robert P. Erickson * \\ Department of Human Genetics, University of Michigan Medical School, Box 015, 1137 E. Calherine Street, \\ Ann Arbor, MI 48109, U.S.A.
}

(Accepted 28 October 1983)

\begin{abstract}
We have examined effects of an autosomal gene on the expression of serologically detectable $\mathrm{H}-\mathrm{Y}$, a male-specific minor histocompatibility antigen for which a role in primary sex determination has been postulated. Quantitative immunoabsorption studies using three different male specific antisera revealed variation in the level of $\mathrm{H}-\mathrm{Y}$ among inbred mouse strains and mice bearing variants of the $T / t$ complex. Two patterns of expression in inbred strains were observed; high, C57BL/6J (B6) and low, which included $\mathrm{A} / \mathrm{J}(\mathrm{A}), \mathrm{C} 3 \mathrm{H} / \mathrm{DiSn}$ and $\mathrm{DBA} / 2 \mathrm{~J}$. In $\mathrm{F}_{1}$ hybrids between $\mathrm{A}$ (female parent) and B6 (male parent), the $\mathrm{F}_{1}$ expressed $\mathrm{H}-\mathrm{Y}$ levels indistinguishable from $\mathrm{A}$, the low parent. Among $T / t$ complex variants, mice bearing $T$ or $t^{0}$ showed high expression whereas those of the $t^{12}$ haplotype showed low expression. The co-segregation of $\mathrm{H}-\mathrm{Y}$ expression types with these $T / t$ complex variants provided further evidence for the location of a gene determining the level of $\mathrm{H}-\mathrm{Y}$ antigen on the proximal portion of chromosome 17.
\end{abstract}

Key words: H-Y antigen; serological H-Y; sex determination; mouse chromosome 17; immunogenetics

\section{Introduction}

Since its discovery by Eichwald and Silmser (1955), many laboratories have confirmed the existence of male specific antigen(s). The early work involved histocompatibility assays and, since maleness is determined by the $\mathrm{Y}$ chromosome in the mammals in which it was studied, it was called histocompatibility-Y or H-Y. The data for Y-linkage was never firm (Erickson, 1977). More recently, serologically detected male specific antigens have been found and, because of their similar dependence on maleness, they have been assumed to be the same H-Y detected in another manner (Goldberg et al., 1971; Scheid et al., 1972). However, at least in man, unique chromosomal Y-linkage of the structural locus has been excluded (Wachtel, 1980). Recently, an argument against equating serological and histocompatible $\mathrm{H}-\mathrm{Y}$ (we are now using $\mathrm{H}-\mathrm{Y}$ as it is commonly used, i.e. as a term for

\footnotetext{
* Correspondence to: Robert P. Erickson, M.D., Imperial Cancer Research Fund Laboratories, P.O. Box 123, Lincoln's Inn Fields, London WC2A 3PX, U.K.
} 
male specific antigen(s)) has been developed because of data obtained from XO mice. Serologically detected H-Y antigen has been found in XO (female) mice (Engel et al., 1981) while histocompatibility detected H-Y was not found (Simpson et al., 1982). However, these results are from different laboratories and the genetic background of the XO mice may be different between them. We have found that the effects of $H y e$, a locus thought to regulate the level of histocompatibility-Y (Králová and Démant, 1976) can also be detected by quantitative immunoabsorption. Hye was defined as governing H-Y 'antigenic strength' in the popliteal lymph node enlargement assay, a test system which measures a cell-mediated response. The effects of this locus have been mapped somewhat nearer to the Brachyury $(T)$ than the H-2 complex on chromosome 17 (Králová and Lengerová, 1979). Thus, a chromosomal 17 locus affects the amount of serologically and histocompatibility detected H-Y in a parallel fashion. This may be: (1) a fortuitous co-incidence, (2) the result of an $H y e$ effect on maleness per se with secondary effects on male specific antigens, or (3) the result of quantitative variation in a molecule that can be detected by both serological and histocompatible methods.

\section{Materials and Methods}

\section{Animals}

A/HeJ, B6 and DBA/2J mice were bred from stocks obtained from the Jackson Laboratories, Bar Harbor, Maine. C3H/DiSn $(\mathrm{C} 3 \mathrm{H})$ mice were bred from a stock provided by Dr. Hugh O. McDevitt, Stanford University School of Medicine, Palo Alto, CA. CF-1 mice were obtained from Charles River Laboratories, Wilmington, MA. $T / t^{\mathrm{n}}$ strains were bred from animals provided by Dr. Salome GluecksohnWaelsch, Albert Einstein College of Medicine, Bronx, New York. All lines were maintained by brother-sister mating.

\section{Preparation of epidermal cells}

Epidermal cells were prepared by the method of Scheid et al. [4]. Mature male B6 mice were killed and the entire piece of skin covering the tail removed. The tail skin was incubated in Puck's Saline F (PSF, Puck et al., 1958) containing 1\% trypsin $\left(2 \times\right.$ crystallized GIBCO) for $50 \mathrm{~min}$ at $37^{\circ} \mathrm{C}$ in order to separate dermis and epidermis. The dermis was discarded and the epidermis placed in Medium 199 (GIBCO) containing 10\% heat inactivated fetal calf serum (FCS). Epidermal cell clumps were teased free of the epidermis by gentle scraping with the tip of a bent, fire-polished Pasteur pipette. These clumps were incubated in PSF containing $0.1 \%$ trypsin for $15-20 \mathrm{~min}$ at $37^{\circ} \mathrm{C}$ in order to yield a suspension of single cells. After this incubation, a two-fold excess of Medium 199 with $10 \%$ FCS was added to the incubation mixture. The resultant cells were pelleted by centrifugation at $100 \times g$ at $4^{\circ} \mathrm{C}$, then washed three times in Medium 199 containing 10\% FCS. Residual multicell clumps were removed by centrifugation at $10-20 \times \mathrm{g}$. The final suspension of epidermal cells was then adjusted to a concentration of approximately $3 \times 10^{6}$ 
cells per $\mathrm{ml}$ for use in the direct cytotoxicity test. Only cell preparations with viabilities in excess of $85 \%$ (as determined by trypan blue exclusion) were used.

\section{Preparation of sperm}

Mature male mice were sacrificed and their epididymides removed. The epididymides were placed in Beatty's salt solution (Erickson and Martin, 1974), minced with a sharp scalpel, then passed through a screen in order to remove large pieces of tissue. The resultant suspension was left for $10 \mathrm{~min}$ at $1 \times g$ to enable large-sized clumps of debris to settle out. Sperm were then pelleted by centrifugation at $800 \times g$ and the pellet washed three times in Beatty's salt solution.

\section{Preparation of splenocytes}

Mature mice were sacrificed and their spleens removed. The spleens were placed in Dulbecco's phosphate buffered saline (PBS, Dulbecco and Vogt, 1954), minced, and teased through a screen. The resultant suspension was left for $10 \mathrm{~min}$ at $1 \times \mathrm{g}$ to enable large-sized stromal elements to settle out. Splenocytes were pelleted at $400 \times \mathrm{g}$ and the pellet washed 2 times in $0.83 \% \mathrm{NH}_{4} \mathrm{Cl}, 2$ times in PBS, then suspended in Medium 199 with 10\% FCS and incubated on ice for 30 min before absorption.

\section{Direct cytotoxicity test}

The procedure used to test H-Y antisera is similar to that of Scheid et al. (1972). Equal volumes ( 10 or $20 \mu \mathrm{l}$ of $0.2 \%$ dye) were added for the final $5 \mathrm{~min}$ of incubation to stain dead epidermal cells. Cell killing was measured by cytotoxic index $(i)$ defined as:

\section{no. dead cells - no. cells killed by complement alone}

total no. cells - no. cells killed by complement alone

Representative cytotoxicity tests were run on series of coded antiserum samples. Of all series of cytotoxicity tests performed, only one was discarded. In this test, the number of cells lysed by complement alone, complement plus unabsorbed H-Y antiserum, and complement plus completely absorbed $\mathrm{H}-\mathrm{Y}$ antiserum were indistinguishable. The data presented in this report include the results of all other direct cytotoxicity tests performed.

\section{Absorptions}

Aliquots of $\mathrm{H}-\mathrm{Y}$ antiserum ( 25 or $50 \mu \mathrm{l}$ ) diluted 1/4 with Medium 199 containing $10 \%$ FCS were added to known numbers of splenocytes. These suspensions were incubated on ice for $1 \mathrm{~h}$. After the period of incubation, the absorbing cells were removed from the absorbed antiserum by centrifugation at the centrifugal force appropriate for pelleting them (above). The resultant antisera were then tested for residual direct cytotoxicity against isolated male murine epidermal cells. Each individual series of absorptions was performed using sperm or splenocytes pooled from 2 to 3 mice. 


\section{Antisera}

Mouse $\mathrm{H}-\mathrm{Y}$ antiserum produced in B6 mice were generated as described by Krco and Goldberg (1976) by immunizing females with syngeneic male splenocytes. H-Y antiserum from $\mathrm{C} 3 \mathrm{H}$ mice were obtained by bleeding multiparous females who had delivered at least 4 litters. Serum samples from these animals were collected $1 \mathrm{wk}$ after the final litter's birthdate. Rat H-Y antiserum was prepared by the method of Fellous et al. (1978) by immunizing female Fisher rats with male (Fisher) splenocytes. Prior to use in quantitative absorption experiments, all antisera were heat inactivated $\left(56^{\circ} \mathrm{C}, 30 \mathrm{~min}\right)$. In addition, the rat antiserum was absorbed with equal volumes of female murine splenocytes for $1 \mathrm{~h}$ at both 0 and $37^{\circ} \mathrm{C}$. An antiserum was judged as H-Y specific if: (1) it had cytotoxic activity against male but not female B6 epidermal cells, and (2) this activity could be removed by male but not female B6 splenocytes.

\section{Data analysis}

Values of $N_{50}$, the number of cells which absorbed $50 \%$ of total cytotoxic activity were determined by extrapolation directly from curves of $i$ versus number of absorbing cells of the type shown in Fig. 1. In Tables 1-6 the ratios shown are values of $\mathrm{N}_{50}$ (Hye low strain) $\div \mathrm{N}_{50}$ (Hye high strain), computed for data generated in a single series of absorptions and cytotoxicity tests.

For data pooled from different series of absorptions and cytotoxicity tests (Table 7), the ratios shown are as defined above, only using $N_{50}$ values which are the arithmatic means from multiple absorptions and cytotoxicity tests run on different days. Propagated standard errors for pooled estimators represent the root mean square values of relative errors in $N_{50}$ for each of the two strains compared, multiplied by the ratio of $N_{50}$ means.

\section{Results}

Quantitative immunoabsorptions were carried out to compare inbred strains of mice for their levels of serological $\mathrm{H}-\mathrm{Y}$ antigen. The experimental design involved comparing different strains in pairwise fashion. The residual cytotoxic activity of each absorbed antiserum sample was then determined by direct cytotoxicity against male B6 murine epidermal cells in the presence of complement.

A comparison was made between splenocytes from males of the $\mathrm{B} 6$ and $\mathrm{C} 3 \mathrm{H}$ strains which had been reported to behave differently in the popliteal lymph node enlargement assay and the epidermal cell cytotoxicity test (Scheid et al., 1972; Králová and Démant, 1976). Figure 1 shows a graph of cytotoxic index, a measure of direct cytotoxic activity, versus number of absorbing cells. B6 splenocytes were more effective than those of the $\mathrm{C} 3 \mathrm{H}$ strain at removing $\mathrm{H}-\mathrm{Y}$ specific serological activity (Fig. 1). The data from three experiments using either mouse or rat anti-H-Y antiserum are summarized in Table 1 . Each experiment is represented by the number of cells which absorbed $50 \%$ of total cytotoxic activity for $\mathrm{B} 6\left(N_{50}(\mathrm{~B} 6)\right)$ and $\mathrm{C} 3 \mathrm{H}\left(\mathrm{N}_{50}(\mathrm{C} 3 \mathrm{H})\right)$ splenocytes, as well as the ratio of $N_{50}(\mathrm{C} 3 \mathrm{H})$ to $N_{50}(\mathrm{~B} 6)$. This ratio 


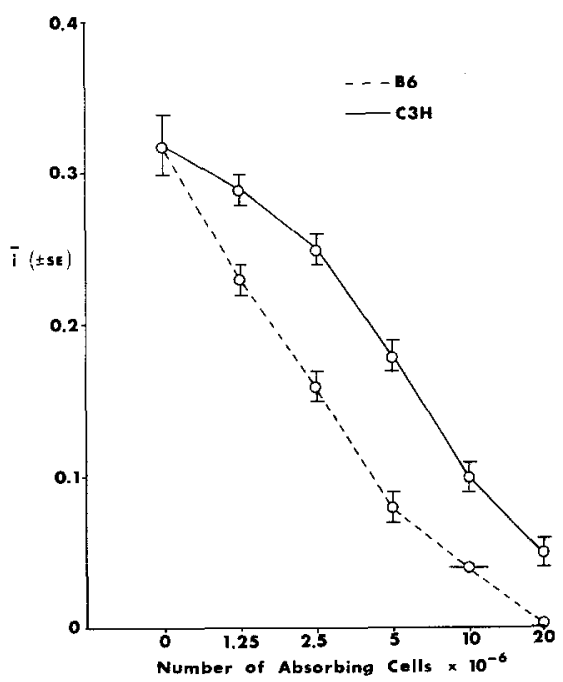

Fig. 1. Quantitative immunoabsorption mouse (B6 anti-B6) anti-H-Y: comparison of B6 versus $\mathrm{C} 3 \mathrm{H}$ male splenocytes. Each value of cytotoxic index $(i)$ represents the mean \pm SEM of duplicate samples, all tested on the same day. Complement control was $23 \%$. Representative test.

provides a rough estimate of the level of serological $\mathrm{H}-\mathrm{Y}$ antigen on $\mathrm{B} 6$ relative to $\mathrm{C} 3 \mathrm{H}$ splenocytes in a single experiment. In all experiments, consistently greater numbers of $\mathrm{C} 3 \mathrm{H}$ than $\mathrm{B} 6$ splenocytes were necessary to remove $50 \%$ of total cytotoxicity activity from aliquots of $\mathrm{H}-\mathrm{Y}$ antisera. The data also suggest that male B6 splenocytes possess about 2.4 times as much serological H-Y antigen on their surfaces as male $\mathrm{C} 3 \mathrm{H}$ splenocytes (Table 1 ). These results are consistent with those of Králová and Démant (1976), in which B6 mice were typed as 'high' and C3H 'low' for alleles of Hye using the popliteal lymph node enlargement assay.

An alternative interpretation of these data is that the absorption differences between $\mathrm{B} 6$ and $\mathrm{C} 3 \mathrm{H}$ are due to strain differences in the antigenic specificities of serologically detectable $\mathrm{H}-\mathrm{Y}$. We addressed the issue of serological $\mathrm{H}-\mathrm{Y}$ specificity differences between $\mathrm{B} 6$ and $\mathrm{C} 3 \mathrm{H}$ by examining sera from multiparous $\mathrm{C} 3 \mathrm{H}$ females.

\section{TABLE 1}

Quantitative immunoabsorptions comparing B6 versus $\mathrm{C} 3 \mathrm{H}$ male splenocytes

\begin{tabular}{llll}
\hline H-Y & \multicolumn{2}{l}{$N_{50} \times 10^{-6}$} & $N_{50}(\mathrm{C} 3 \mathrm{H}) / N_{50}(\mathrm{~B} 6)$ \\
\cline { 2 - 3 } $\begin{array}{lll}\text { antiserum } \\
\text { Rat }\end{array}$ & $\mathrm{C} \mathrm{H}$ & $\mathrm{B} 6$ & 1.52 \\
Mouse & 5.00 & 3.30 & 2.48 \\
Mouse & 6.20 & 2.50 & 3.06 \\
& 5.20 & 1.70 & $2.35 \pm 0.45$ \\
\hline
\end{tabular}

Each row summarizes the results of a complete series of absorptions and cytotoxicity tests. The second row summarizes the data shown in Fig. 1. 

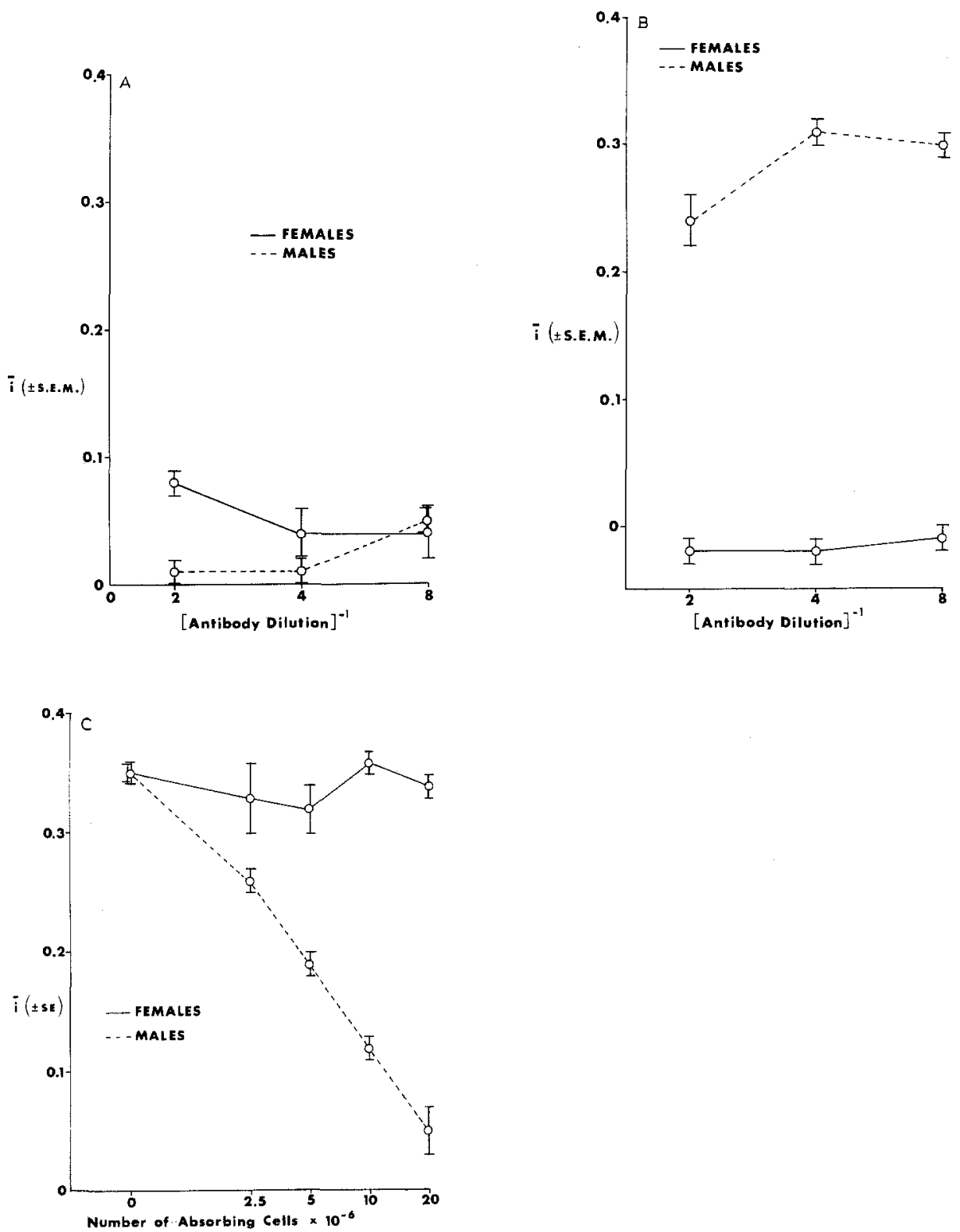

Fig. 2. Serological specificity of H-Y antibodies made in multiparous $\mathrm{C} 3 \mathrm{H}$ female mice. (A) Cytotoxicity against male versus female $\mathrm{C} 3 \mathrm{H}$ epidermal cells. Each value of $i$ represents the mean $\pm \mathrm{SEM}$ of triplicate cytotoxicity tests. Complement controls were 17\% (female targets) and 20\% (male targets). (B) Cytotoxicity against male versus female B6 epidermal cells. Each value of $i$ represents the mean \pm SEM of triplicate cytotoxicity tests. Complement controls were 25\% (female targets) and 19\% (male targets). (C) Absorption with male versus female $\mathrm{C} 3 \mathrm{H}$ splenocytes. Residual cytotoxicity was tested against male B6 epidermal cells. Each value of $i$ represents the mean \pm SEM of duplicate cytotoxicity tests. Complement control was $24 \%$. 
These sera are thought to contain cytotoxic anti-H-Y antibodies (Krupen-Brown and Wachtel, 1979). Epidermal cell cytotoxicity tests were performed with these sera against target cells of either $\mathrm{C} 3 \mathrm{H}$ or $\mathrm{B} 6$ origin in the presence of complement. In the tests against $\mathrm{C} 3 \mathrm{H}$ targets, the $\mathrm{C} 3 \mathrm{H}$ sera proved neither effective or male-specific (Fig. 2A). These sera, however, were effective in producing appreciable male-specific cytolysis against epidermal cells of B6 origin (Fig. 2B). As further evidence of anti-H-Y (male) specificity, aliquots of this antibody were absorbed with various numbers of male or female $\mathrm{C} 3 \mathrm{H}$ splenocytes, then tested for residual cytotoxic activity against male B6 epidermal cells. Whereas female cells did not remove H-Y serological activity in a dose-dependent fashion, this activity was effectively absorbed by male cells (Fig. 2C). Therefore, $\mathrm{H}-\mathrm{Y}$ antibodies made in $\mathrm{C} 3 \mathrm{H}$ mice are more effectively cytolytic against $\mathrm{B} 6$ than $\mathrm{C} 3 \mathrm{H}$ epidermal cells and can be absorbed by $\mathrm{C} 3 \mathrm{H}$ male cells. Since anti-H-Y antibodies made in $\mathrm{B} 6$ mice show the same cytotoxic pattern (Scheid et al., 1972), it is unlikely that the absorption profile difference observed between $\mathrm{B} 6$ and $\mathrm{C} 3 \mathrm{H}$ males is due to differences in serological H-Y specificity.

Males of two other inbred strains of mice, A and DBA/2J, were each compared with B6 as to their level of splenocyte $\mathrm{H}-\mathrm{Y}$. In the case of $\mathrm{A}$, the $N_{50}$ observed was roughly twice that of B6 (Table 2). The contrast involving DBA/2J provided results similar in direction. For this comparison, the $N_{50}$ for DBA/2J was approximately 2.5 times that of B6, implying that B6 splenocytes possess 2.5 times the serological $\mathrm{H}-\mathrm{Y}$ detectable on DBA/2J cells (Table 2).

$\mathrm{F}_{1}$ hybrid males from a mating of $\mathrm{A}$ and $\mathrm{B} 6$ were also examined. The $N_{50}$ shown by the $F_{1}$ animals was an average of 2.4 times that of the B6 parent (Table 2). Hence, the $(\mathrm{A} \times \mathrm{B} 6) \mathrm{F}_{1}$ is indistinguishable from the $\mathrm{A}$, or low parent (Table 2). Since B6 provided the $\mathrm{Y}$ chromosome, $\mathrm{Y}$-linkage was also excluded.

In addition to inbred strains of mice, variation in the level of serological H-Y antigen was also investigated in variants of the murine $T$-complex. Splenocytes from males of $+/ T$ and $+/ t^{12}$ genotypes were compared for their ability to absorb $\mathrm{H}-\mathrm{Y}$ antibodies. One contrast was between littermates from the cross $\mathrm{A} / \mathrm{HeJ} \times T / t^{12}$.

\section{TABLE 2}

Quantitative immunoabsorptions comparing $\mathrm{B} 6$ versus $\mathrm{A}, \mathrm{DBA}$, and $(\mathrm{A} \times \mathrm{B} 6) \mathrm{F}_{1}$ male splenocytes

\begin{tabular}{|c|c|c|c|c|c|}
\hline \multirow[t]{2}{*}{ Test strain (TS) } & \multicolumn{2}{|c|}{$N_{50} \times 10^{-6}$} & \multicolumn{3}{|c|}{$N_{50}(\mathrm{TS}) / N_{50}(\mathrm{~B} 6)$} \\
\hline & TS & B6 & $\begin{array}{l}\text { Individual } \\
\text { values }\end{array}$ & Mean & SEM \\
\hline \multirow[t]{2}{*}{ A } & 2.12 & 1.44 & 1.47 & \multirow{2}{*}{2.01} & \multirow{2}{*}{0.54} \\
\hline & 3.12 & 1.22 & 2.56 & & \\
\hline \multirow[t]{2}{*}{ DBA } & 3.90 & 1.52 & 2.57 & \multirow{2}{*}{2.50} & \multirow{2}{*}{0.07} \\
\hline & 3.79 & 1.56 & 2.43 & & \\
\hline \multirow[t]{2}{*}{$(\mathrm{A} \times \mathrm{B} 6) \mathrm{F}_{1}$} & 4.48 & 1.95 & 2.30 & \multirow{2}{*}{2.40} & \multirow{2}{*}{0.10} \\
\hline & 2.95 & 1.18 & 2.50 & & \\
\hline
\end{tabular}

All experiments were performed using mouse H-Y antiserum. Each row summarizes the results of a complete series of absorptions and cytotoxicity tests. 
TABLE 3

Quantitative immunoabsorptions comparing $+/ T$ versus $+/ t^{12}$ male splenocytes

\begin{tabular}{|c|c|c|c|c|c|}
\hline \multirow{2}{*}{$\begin{array}{l}\text { Female } \\
\text { parent }\end{array}$} & \multirow[t]{2}{*}{ [Antibody dilution] $^{-1}$} & \multicolumn{2}{|c|}{$N_{50} \times 10^{-7}$} & \multicolumn{2}{|c|}{$N_{50}\left(+/ t^{12}\right) / N_{50}(+/ T)$} \\
\hline & & $+/ t^{12}$ & $+/ T$ & $\begin{array}{l}\text { Individual } \\
\text { values }\end{array}$ & Mean \pm SEM \\
\hline $\mathrm{A} / \mathrm{HEJ}$ & 4 & 1.60 & 0.85 & 1.89 & - \\
\hline \multirow[t]{4}{*}{ CF-1 } & 4 & 1.69 & 1.16 & 1.46 & \multirow[t]{4}{*}{$1.50 \pm 0.07$} \\
\hline & 8 & 2.11 & 1.25 & 1.69 & \\
\hline & 16 & 1.47 & 1.09 & 1.35 & \\
\hline & 32 & 1.74 & 1.15 & 1.51 & \\
\hline
\end{tabular}

All experiments were performed using mouse H-Y antiserum. Each row summarizes the results of a complete series of absorptions and cytotoxicity tests. All absorptions were performed at an antibody dilution of $1: 4$.

The $N_{50}$ determined for the $+/ t^{12}$ animals was 1.89 times that for the $+/ T$ mice (Table 3). We also compared $+/ T$ and $+/ t^{12}$ littermates from the crosses of random-bred CF-1 mice to $T / t^{12}$ using a series of quantitative absorptions which were tested at several dilutions in the epidermal cell cytotoxicity test. At each dilution, the $N_{50}$ value for $+/ t^{12}$ was consistently greater than the $+/ T$ value (ratio $=1.50 \pm 0.07$; Table 3 ). Hence, $+/ T$ animals appear to have 1.5 to 2 times as much serologically detectable $\mathrm{H}-\mathrm{Y}$ antigen on their splenocytes as their $+/ t^{12}$ littermates. Although this would indicate that $t^{12}$ and $T$ are associated with low and high levels respectively of H-Y determinants, it remained to be established whether this quantitative variation was due to the same genetic entity as that seen in inbred strains of mice. Further studies were therefore carried out with the splenocytes of males bearing one chromosome 17 from an inbred mouse strain and the other from a $T / t$ complex variant.

$\mathrm{C} 3 \mathrm{H} / t^{12}$ littermates from the cross $\mathrm{C} 3 \mathrm{H} \times T / t^{12}$ were compared with age-matched $\mathrm{C} 3 \mathrm{H}$ males. The $N_{50}$ values obtained for these males were not significantly different from one another (Table 4). This suggests that animals possessing low H-Y expression factors of both $\mathrm{C} 3 \mathrm{H}$ and $t^{12}$ origin are not detectably different in their antigen

\section{TABLE 4}

Quantitative immunoabsorptions comparing $\mathrm{C} 3 \mathrm{H}$ versus $\mathrm{C} 3 \mathrm{H} / t^{12}$ and $\mathrm{B} 6$ versus $\mathrm{A} / t^{12}$ male splenocytes

\begin{tabular}{|c|c|c|c|c|c|}
\hline \multirow{2}{*}{$\begin{array}{l}\text { Test strain-1 } \\
\text { (TS-1) }\end{array}$} & \multirow{2}{*}{$\begin{array}{l}\text { Test strain-2 } \\
\text { (TS-2) }\end{array}$} & \multicolumn{2}{|c|}{$N_{50} \times 10^{-6}$} & \multicolumn{2}{|c|}{$N_{50}(\mathrm{TS}-1) / N_{50}(\mathrm{TS}-2)$} \\
\hline & & TS-1 & TS-2 & $\begin{array}{l}\text { Individual } \\
\text { values }\end{array}$ & Mean \pm SEM \\
\hline \multirow[t]{2}{*}{$\mathrm{C} 3 \mathrm{H} / t^{12}$} & \multirow[t]{2}{*}{$\mathrm{C} 3 \mathrm{H}$} & 2.00 & 2.20 & 0.91 & \multirow{2}{*}{$1.02 \pm 0.11$} \\
\hline & & 1.80 & 1.60 & 1.13 & \\
\hline \multirow[t]{2}{*}{$\mathrm{A} / t^{12}$} & \multirow[t]{2}{*}{ B6 } & 4.01 & 1.60 & 2.51 & \multirow{2}{*}{$2.31 \pm 0.19$} \\
\hline & & 3.69 & 1.74 & 2.12 & \\
\hline
\end{tabular}

All experiments were performed using mouse H-Y antiserum. Each row summarizes the results of a complete series of absorptions and cytotoxicity tests. 


\section{TABLE 5}

Quantitative immunoabsorptions comparing $T / t^{0}$ versus $T / t^{12}$ male splenocytes

\begin{tabular}{lll}
\hline$N_{50} \times 10^{-6}$ & \multicolumn{2}{c}{$N_{50}\left(T / t^{12}\right) / N_{50}\left(T / t^{0}\right)$} \\
\hline$T / t^{12}$ & $T / t^{0}$ & 3.73 \\
\hline 10.70 & 2.87 & 1.77 \\
3.54 & 2.00 & $1.84^{\mathrm{a}}$ \\
8.24 & $4.48^{\mathrm{a}}$ & \\
Mean \pm SEM & $2.45 \pm 0.64$ &
\end{tabular}

$t^{29}$ was substituted for $t^{0}$. The two represent the same $t$-haplotype.

All experiments were performed using rat H-Y antiserum. Each row summarizes the results of a complete series of absorptions and cytotoxicity tests.

level from males with low factors solely of $\mathrm{C} 3 \mathrm{H}$ origin. In addition, $\mathrm{A} / t^{12}$ littermates obtained from the $\mathrm{A} \times T / t^{12}$ cross were compared with age-matched $\mathrm{B} 6$ animals. On the assumption that low expression factors of $\mathrm{A}$ and $\mathrm{C} 3 \mathrm{H}$ origin are acting indistinguishably, this provides a contrast reciprocal to that of $\mathrm{C} 3 \mathrm{H} / t^{12}$ and $\mathrm{C} 3 \mathrm{H}$. In this experiment, the $N_{50}$ of $\mathrm{A} / t^{12}$ was approximately 2.3 times that of B6 (Table 4), suggesting that $\mathrm{A}$ and $t^{12}$ low factors in combination act in a manner indiscernible from low factors solely of A (Table 2), $\mathrm{C} 3 \mathrm{H}$ (Table 1) or DBA (Table 2) origin.

Relative levels of splenocyte serological $\mathrm{H}-\mathrm{Y}$ were also determined comparing age-matched males of two genotypes, from balanced lethal stocks, $T / t^{0}$ and $T / t^{12}$. The $t^{0}$ and $t^{12}$ haplotypes are members of different complementation groups according to their effects in trans on embryonic development. Values of $N_{50}$ observed for $T / t^{12}$ were roughly 2.5 times those of $T / t^{0}$ (Table 5). From these data, we can speculate that the $t^{0}$ haplotype behaves as a high expression variant. This speculation, however, is based upon the assumption that both ' $T$ ' chromosomes are indistinguishably Hye high and that the $t^{0}$ chromosome acts in $\mathrm{F}_{1}$ as do other Hye

TABLE 6

Quantitative absorptions comparing $+/ t^{12}$ versus $+/ T$ and $T / t^{12}$ versus $T / t^{0}$ sperm

\begin{tabular}{|c|c|c|c|c|c|c|c|}
\hline \multirow{2}{*}{$\begin{array}{l}\text { Test animal-1 } \\
\text { (TA-1) }\end{array}$} & \multirow{2}{*}{$\begin{array}{l}\text { Test animal-2 } \\
\text { (TA-2) }\end{array}$} & \multirow{2}{*}{$\begin{array}{l}\text { female } \\
\text { parent }\end{array}$} & \multirow[t]{2}{*}{ [Antibody dilution] $^{-1}$} & \multicolumn{2}{|c|}{$N_{50} \times 10^{-6}$} & \multicolumn{2}{|c|}{$N_{50}(\mathrm{TA}-1) / N_{50}(\mathrm{TA}-2)$} \\
\hline & & & & TA-1 & TA-2 & $\begin{array}{l}\text { Individual } \\
\text { values }\end{array}$ & Mean $\pm \mathrm{SEM}$ \\
\hline$+/ t^{12}$ & $+/ T$ & $\mathrm{~A} / \mathrm{HEJ}$ & 4 & 1.84 & 0.81 & 2.27 & - \\
\hline \multirow[t]{4}{*}{$+/ t^{12}$} & $+/ T$ & $\mathrm{CF}-1$ & 4 & 1.60 & 0.91 & 1.76 & \\
\hline & & & 8 & 1.79 & 1.00 & 1.79 & \\
\hline & & & 16 & 0.97 & 0.66 & 1.47 & $1.70 \pm 0.08$ \\
\hline & & & 32 & 1.12 & 0.63 & 1.77 & \\
\hline$T / t^{12}$ & $T / t^{0}$ & $+/ T$ & 4 & 2.80 & 1.08 & 3.73 & - \\
\hline
\end{tabular}

All experiments were performed using mouse $\mathrm{H}-\mathrm{Y}$ antiserum with the exception of the $T / t^{12}$ versus $T / t^{0}$ comparison which was performed using rat $\mathrm{H}-\mathrm{Y}$ antiserum. Each row summarizes the results of a complete series of absorptions and cytotoxicity tests. All absorptions were performed at an antibody dilution of $1: 4$. 
high chromosomes. On these assumptions our results provide a contrast much like the $\mathrm{B} 6$ versus $(\mathrm{A} \times \mathrm{B} 6) \mathrm{F}_{1}$ comparison in inbred mice.

We also performed comparisons of $T$-complex variants with sperm as the absorbing cell type. Comparison of $+/ T$ and $+/ t^{12}$ littermates derived from the $\mathrm{A} / \mathrm{HeJ} \times$ $T / t^{12}$ cross provided results identical in direction with those obtained in splenocyte absorptions. In this contrast, the $N_{50}$ of $+/ t^{12}$ was 2.27 that of $+/ T$ with sperm (Table 6). The corresponding ratio with splenocytes was 1.89 . A contrast was also made between $+/ T$ and $+/ t^{12}$ littermates from the outcross of $T / t^{12}$ to $\mathrm{CF}-1$. As in the identical splenocyte contrast, a series of quantitative absorptions were tested in the epidermal cell cytotoxicity test at several dilutions. As in the splenocyte absorptions, the $N_{50}$ values for $+/ t^{12}$ were consistently greater than those for $+/ T$ (ratio $=1.70 \pm 0.08 ;$ Table 6 ). The comparison of $T / t^{0}$ and $T / t^{12}$ sperm was also made. Again, the $N_{50}$ value for $T / t^{12}$ was greater than that for $T / t^{0}$ (ratio $=3.73$; Table 6), a result consistent with our data for splenocytes.

\section{Discussion}

The quantitative immunoabsorption data were analyzed in two ways by generating ratios between $N_{50}$ values generated in a single experiment as well as ratios and standard errors pooling $N_{50}$ values for each of the strains within a comparison as determined on different days. We conclude that whether the results of each strain contrast are considered experiment-by-experiment, or as a pooled data set, the $N_{50}$ ratio and standard error values obtained are comparable (Table 7).

Inbred mice fall within two groupings for amount of serological H-Y: high (B6) and low (A, C3H, and DBA/2J). Among males containing variants of the $T$-complex, animals bearing either $T$ or the $t^{0}$ haplotype manifested more splenocyte and sperm H-Y antigen than those bearing the $t^{12}$ haplotype. In terms of Hye, this may

\section{TABLE 7}

Alternative analyses of quantitative immunoabsorption data

\begin{tabular}{|c|c|c|c|c|c|}
\hline \multirow{2}{*}{$\begin{array}{l}\text { Test strain-1 } \\
\text { (TS-1) }\end{array}$} & \multirow{2}{*}{$\begin{array}{l}\text { Test strain-2 } \\
\text { (TS-2) }\end{array}$} & \multicolumn{2}{|c|}{${ }^{\mathrm{a}} N_{50}(\mathrm{TS}-1) / N_{50}(\mathrm{TS}-2)$} & \multicolumn{2}{|c|}{${ }^{\mathrm{b}} N_{50}(\mathrm{TS}-1) / N_{50}(\mathrm{TS}-2)$} \\
\hline & & Mean & SEM & Mean & SEM \\
\hline $\mathrm{C} 3 \mathrm{H}$ & B6 & 2.35 & 0.45 & 2.19 & 0.45 \\
\hline A & B6 & 2.01 & 0.54 & 1.97 & 0.41 \\
\hline DBA & B6 & 2.50 & 0.07 & 2.50 & 0.05 \\
\hline$(\mathrm{A} \times \mathrm{B} 6) \mathrm{F}_{1}$ & B6 & 2.40 & 0.10 & 2.37 & 0.77 \\
\hline $\mathrm{C} 3 \mathrm{H} / t^{12}$ & $\mathrm{C} 3 \mathrm{H}$ & 1.02 & 0.11 & 1.00 & 0.17 \\
\hline $\mathrm{A} / t^{12}$ & B6 & 2.31 & 0.19 & 2.31 & 0.14 \\
\hline$T / t^{12}$ & $T / t^{0}$ & 2.45 & 0.64 & 2.40 & 0.89 \\
\hline
\end{tabular}

a Generated by pooling individual ratio values shown in Tables 1, 2, 4 and 5 and computing sample means and standard errors.

${ }^{b}$ Generated by computing sample means and standard errors for the $N_{50}$ values shown in Tables $1,2,4$ and 5. Ratio means represent the ratio of these averages. SEM values represent the propagated errors for each ratio. 
be accounted for by $t^{0}$ having 'locked in' the high and $t^{12}$ the low allele as the result of cross-over suppression within the $T$-complex.

We also studied the behaviour of high and low alleles together in trans. In the case of the $F_{1}$ between $A$ (female parent) and B6 (male parent) the $F_{1}$ appeared indistinguishable from the low parent (A). One of two interpretations of this result are possible, either the low is dominant to the high Hye allele or the two are codominant implying that 'intermediate' levels of H-Y expression are not detectable in our assay. In addition, we studied the interaction between high and low alleles in balanced lethal $\left(T / t^{\mathrm{n}}\right)$ mice bearing the $t^{0}$ and $t^{12}$ haplotypes. Assuming that $t^{0}$ males express high $\mathrm{H}-\mathrm{Y}$ levels, and that both $T$ chromosomes possess equivalent high genetic factors, the balanced lethal possessing both high and low alleles is indistinguishable from animals with alleles solely of the low type, since the $N_{50}$ ratio between $T / t^{12}$ and $T / t^{0}$ is not significantly different from the one between $\mathrm{C} 3 \mathrm{H}$ and B6 (Table 3 and Table 1).

The genes which govern this pattern of variation appear to reside on proximal chromosome 17 as evidenced by their co-segregation with $T$-complex variants (no cross-overs in 10 outcrossed mice, $\chi^{2}=5, P<0.05$ ). These mutations are present on a 15 centiMorgan (cM) region of chromosome 17 which extends from a point roughly $3 \mathrm{cM}$ from the centromere to the $H-2$ complex (Bennett, 1975; Erickson et al., 1980). Both $T$ and $t$ mutations govern tail length and embryonic lethality. The $t$-haplotypes also affect the maturation and function of male germ cells and suppress recombination between the chromosomes on which they reside and homologous normal chromosomes (Gluecksohn-Waelsch and Erickson, 1970; Klein and Hammerberg, 1977).

Because of the concordance with the results reported by Králová and co-workers (Králová and Démant, 1976; Králová and Lengerová, 1979), we believe that our serological variants represent alleles of the H-Y antigen expression, or Hye locus, which maps proximal to the $H-2$ complex on chromosome 17 . There are distinctions between our inferences and those of Králová and co-workers, however. The Hye phenomenon was originally defined on the basis of the response evoked by high or low allele donor thymocytes in the popliteal lymph node enlargement assay. An interpretation of the data generated by this technique is that the high and low alleles in Hye represent, respectively, strongly and weakly immunogenic forms of tissue graft H-Y. Our results support a direct association between high and low alleles and serological antigen levels on splenocytes, but the correlation could be coincidental.

Our results are compatible with those of Scheid et al. (1972) who reported that in the epidermal cell and sperm cytotoxicity tests using $\mathrm{H}-\mathrm{Y}$ antibody made in B6 female mice, B6 target cells were lysed more effectively than $\mathrm{C} 3 \mathrm{H}$ targets. Strain differences in the level of cell surface H-Y antigen, however, was not the only possible explanation. Alternative explanations include strain differences in the antigenic specificities of serological H-Y and strain differences in susceptibility to complement-mediated cytotoxicity. Although the latter explanation is not relevant given our test system, the former hypothesis could have accounted for our results. We have observed, however, that $\mathrm{H}-\mathrm{Y}$ antibody made in $\mathrm{C} 3 \mathrm{H}$ mice lysed $\mathrm{B} 6$ epidermal cells more effectively than it did $\mathrm{C} 3 \mathrm{H}$ targets. This result suggests that it is 
unlikely that the strain variation in absorption we have detected is due to differences in the antigenic specificities of serological H-Y antigen.

$\mathrm{H}-\mathrm{Y}$ antibodies are thought to cross-react with cell surface determinants from the heterogametic sexes of species as phylogenetically distant as frogs and humans (Wachtel, 1979). In mammals, the findings that male tissue from every species studied reacts as $\mathrm{H}$-Y-positive has led to speculation that $\mathrm{H}-\mathrm{Y}$ antigen is a male determining substance (Wachtel et al., 1975). Our evidence is consistent with the involvement of genes other than those classically associated with sex determination in serological H-Y antigen expression. Since mapping studies place $H y e$ within the $T / t$ complex (Králová and Lengerová, 1979), it is plausible that there is association, linkage, or identity of $H y e$ with loci which are thought to govern the maturation and function of male germ cells. An extensive analogy may be drawn between our studies of splenocyte $\mathrm{H}-\mathrm{Y}$ antigen levels in $T / t$ complex variants and the work of Artzt and Bennett which supported an inverse relationship between $t^{\mathrm{w} 32}$ (an allele of the $t^{12}$ complementation group first isolated from wild mouse populations) and F9 antigen on sperm (Artzt et al., 1974; Marticorena et al., 1978; Ben-Shaul et a1., 1981). F9, much like H-Y (Shapiro and Erickson, 1981), is an antigen whose serological recognition is thought to involve a polysaccharide structure that contains galactosyl moieties (Maramatsu et al., 1979; Prujansky-Jacobvits et al., 1979). The similarity between the quantitative $\mathrm{H}-\mathrm{Y}$ variation we have observed and the kind reported for F9 differentiation antigen suggests that the appearance of glycoconjugate differentiation antigens may be controlled by associated, or even common, genetic functions. Support for this notion includes the association of galactosyltransferase activity variants with the $T$-complex (Shur and Bennett, 1979), although inbred strains of mice varied in galactosyltransferase levels at least as much as the $T$-complex variants examined. When galactosyltransferase assays were performed using purified ovomucoid as acceptor, no direct correlation between enzyme activity and Hye was observed (Shapiro, 1982).

Although Hye is located on the murine chromosome 17, what relationship might it have with sequences on the Y? Despite association of the antigen's appearance with Y-chromosomal elements, the precise location of the 'structural gene' for the $\mathrm{H}-\mathrm{Y}$ molecule has thus far eluded definition. Consequently, any and almost every location has been postulated (Wachtel, 1980). Perhaps some of the locations reported govern quantitative regulators of the kind we propose rather than structural elements. It is of interest that variations in the number of ' $Y$ chromosome equivalents' were also detected serologically (Shapiro et al., 1982).

\section{Acknowledgements}

This work was supported by grant HD 11738 and Training Grant GM 7544 from N.I.H. We thank Drs. Craig Hammerberg and Susan Lewis for breeding some of the mice used in this study, Dr. Craig Hammerberg for helpful discussions, and Mrs. Rena Jones for typing the manuscript. Portions of this report are included as part of a dissertation submitted by M.S. in partial fulfillment of the Ph.D. degree at the Horace H. Rackham School of Graduate Studies of The University of Michigan. 


\section{References}

Artzt, K., Bennett, D. and Jacob, F. (1974) Primitive teratocarcinoma cells express a differentiation antigen specified by a gene at the T-locus in the mouse. Proc. Natl. Acad. Sci. U.S.A. 71, 811.

Bennett, D. (1975) The T-locus of the mouse. Cell 6, 441.

Ben-Shaul, Y., Babiarz, B. and Bennett, D. (1981) Visualization of the F9 antigen on sperm from normal and $\mathrm{T} / \mathrm{t}$ complex mutants by immunoscanning electron microscopy. Dev. Genet. 2, 171.

Dulbecco, R. and Vogt, M. (1954) Plaque formation and isolation of pure lines with poliomyelitis viruses. J. Exp. Med. 99, 167.

Eichwald, E.J. and Silmser, C.R. (1955) Untitled communication. Transplant. Bull. 2, 148.

Engel, W., Klemme, B. and Ebrecht, A. (1981) Serological evidence for H-Y antigen in XO-female mice. Hum. Genet. 57, 68.

Erickson, R.P. (1977) Androgen-modified expression versus Y-linkage of the male specific antigen. Nature (London) 265, 59.

Erickson, R.P. and Martin, S.R. (1974) The relationship of mouse spermatozoal to mouse testicular cathepsins. Arch. Biochem. Biophys. 165, 114.

Erickson, R.P., Hammerberg, C. and Sanchez, E. (1980) $t$-Mutants in the mouse and alterations in early development. in Current Trends in Craniofacial Development, (R.M. Pratt and R.L. Christiansen, eds.), pp. 103-177. Elsevier/North-Holland, Amsterdam.

Fellous, M., Gunther, E., Kemler, R., Wiels, J., Bereger, R., Guenet, J.L., Jakob, H. and Jacob, F. (1978) Association of $\mathrm{H}-\mathrm{Y}$ male antigen with $\beta$-microglobulin on human lymphoid and differentiated mouse teratocarcinoma cell lines. J. Exp. Med. 148, 58.

Gluecksohn-Waelsch, S. and Erickson, R.P. (1970) The T-locus of the mouse: implications for mechanisms of development. Curr. Top. Dev. Biol. 5, 281.

Goldberg, E.H., Boyse, E.A., Bennett, D., Scheid, M. and Carswell, E.A. (1971) Serological demonstration of H-Y (male) antigen on mouse sperm. Nature (London) 232, 478.

Klein, J. and Hammerberg, C. (1977) The control of differentiation by the T complex. Immunol. Rev. 33, 70.

Králová, J. and Démant, P. (1976) Expression of the H-Y antigen on thymus cells and skin: differential genetic control linked to the $\mathrm{K}$ end of $\mathrm{H}-2$. Immunogenetics 3, 583.

Králová, J. and Lengerová, A. (1979) H-Y antigen: genetic control of the expression as detected by host-versus-graft popliteal lymph node enlargement assay maps between the $\mathrm{T}$ and $\mathrm{H}-2$ complexes. J. Immunogenet. 6, 429.

Krco, C.J. and Goldberg, E.H. (1976) H-Y (male) antigen: detection on 8-cell mouse embryos. Science 193, 1134.

Krupen-Brown, K. and Wachtel, S.S. (1979) Cytotoxic and agglutinating H-Y antibodies in multiparous female mice. Transplantation 27, 406.

Maramatsu, T., Gachelin, G. and Jacob, F. (1979) F9 embryonal carcinoma cells. Biochim. Biophys. Acta $587,392$.

Marticorena, P., Artzt, K. and Bennett, D. (1978) Relationship of F9 antigen and genes of the T/t complex. Immunogenetics 7, 337.

Prujansky-Jacobovits, A., Gachelin, G., Maramatsu, T., Sharon, N. and Jacob, F. (1979) Surface galactosyl glycopeptides of embryonal carcinoma cells. Biochem. Biophys. Res. Comm. 89, 448.

Puck, T.T., Cieciura, S.J. and Robinson, A. (1958) Genetics of somatic mammalian cells. III. Long-term cultivation of euploid cells from human and animal subjects. J. Exp. Med. 108, 945.

Scheid, M., Boyse, E.A., Carswell, E.A. and Old, L.J. (1972) Serologically demonstrable alloantigens of mouse epidermal cells. J. Exp. Med. 135, 938.

Shapiro, M. (1982) Studies on the Molecular Nature of Serologically Detectable H-Y Antigen and the Genetics of its Expression. Ph.D. Thesis, The University of Michigan.

Shapiro, M. and Erickson, R.P. (1981) Evidence that the serological determinant of H-Y antigen is carbohydrate. Nature (London) 290, 503.

Shapiro, M., Erickson, R.P., Lewis, S. and Tres, L.L. (1982) Serological and cytological evidence for increased $\mathrm{Y}$-chromosome related material in $S x r, \mathrm{XY}$ (sex-reversed carrier, male) mice. J. Reprod. Immunol. 4, 191. 
Shur, B.D. and Bennett, D. (1979) A specific defect in galactosyltransferase regulation on sperm bearing mutant alleles at the $T / t$ locus. Dev. Biol. 71, 243.

Simpson, E., McLaren, A. and Chandler, A. (1982) Evidence for two male antigens in mice. Immunogenetics 15,609 .

Wachtel, S.S. (1979) Primary sex determination. H-Y antigen and the development of the mammalian testes. Arthritis Rheum. 22, 1200.

Wachtel, S.S. (1980) Where is the H-Y structural gene? Cell 22, 3.

Wachtel, S.S., Ohno, S., Koo, G.C. and Boyse, E.A. (1975) Possible role for H-Y antigen in the primary determination of sex. Nature (London) 257, 235. 